\title{
Uncomplicated HL-A Matched Sibling Bone Marrow Graft for Combined Immune Deficiency
}

\author{
M. YAMAMURA， R. C. F. NEWTON， D. C. O. JAMES， J. G. HUMBLE， L. J. BUTLER， J. R. HOBBS
}

British Medical fournal, 1972, 2, 265-269

\section{Summary}

When an apparently identical HL-A donor can be found and satisfactorily checked by the mixed lymphocyte reaction, it is worth attempting simple bone marrow grafting in a patient with combined immune deficiency syndrome who otherwise would die. Immunocompetence was given in this way to a baby girl by her 4-year-old brother and was confirmed by the presence of $Y$ chromosome in most of the transforming lymphocytes. IgA was late to emerge, presumably owing to the immaturity for IgA of the donor's bone marrow.

\section{Introduction}

Combined immune deficiency syndrome is regularly fatal, mostly within three months of birth. Elegant techniques for the aseptic delivery of suspected cases (Barnes et al., 1969) and for the fractionation of donor bone marrow grafts (Dicke et al., 1968) have been described and successful grafts have been achieved (Gatti et al., 1968; Koning et al., 1969). These seem beyond the income and facilities of ordinary hospitals, and it has been estimated that some 40 patients a year die untreated in the U.S.A. (F. S. Rosen, personal communication, 1971).

It is now accepted that the thymus appears hypoplastic in such patients not because of an inherent thymic defect but simply because it has not been called on to show its function, in that bone marrow stem cells have not been presented-that is, the thymus merely shows disuse atrophy. If we accept that the requirement is for competent bone marrow stem cells, it seems somewhat illogical to go to great lengths to fractionate out those donor stem cells most likely to cause graft-versus-host reaction. It is these very competent cells that the patient immediately requires. The object of such fractionation was, however, to allow such immunocompetent cells to emerge from stem cells, after grafting, in the presence of an excess of the recipient's antigens whereby it was hoped small incompatibilities might be overcome by high-dose tolerance. The experimental results in monkeys, however, show that the main achievement was to weaken the donor graft, so that the inevitable graft-versus-host reaction (if the graft is not wholly compatible) was delayed (K. A. Dicke, personal communication, 1971).

In reviewing the use of such complicated techniques, it seemed to us that some of the patients died more as a result of inadequate grafting than of graft-versus-host reaction.

It seemed logical to us that either the donor marrow was compatible or it was not, and that since death would otherwise be certain then at least the attempted graft should be as good as possible. Past experience of simply grafting unfractionated

Westminster Hospital Group and Medical School, London S.W.1

M. YAMAMURA, M.sc., Immunochemist, Department of Chemical Pathology

R. C. F. NEWTON, D.C.H., M.R.C.P., Senior Registrar in Paediatrics

D. C. O. JAMES, M.D., M.R.C.PATH., Consultant, Blood Transfusion and Transplantation Immunology

J. G. HUMBLE, F.R.C.P., F.R.C.PATH., Professor of Haematology

J. R. HOBBS, M.D., M.R.C.P., Professor of Chemical Pathology

Queen Elizabeth Hospital for Children, London E.2

L. J. BUTLER, B.SC., M.I.BIol., Senior Cytogeneticist bone marrow was readily available at Westminster Hospital, and this is a technique which should be possible for many more centres. We accordingly report its successful use in one infant who at the time of grafting was dying from widespread infection.

\section{Methods}

Immunoglobulin levels were measured by a modified Mancini method (Hobbs, 1970) and are reported in $\mathrm{mg} / 100 \mathrm{ml}$. The M.R.C. standard serum $67 / 99$ is equivalent by our assays to $\operatorname{IgG} 663$, IgA 174 , and $\operatorname{IgM} 66 \mathrm{mg} / 100 \mathrm{ml}$.

Phagocytosis was assessed both by the candida killing test (Lehrer and Cline, 1969), using both patient's and a known fresh normal AB serum free of isoantibodies, and by a nitroblue tetrazolium test.

Lymphocyte Studies.-Lymphocytes were separated from defibrinated blood after aggregation of red blood cells with dextran 150. A suspension of cells was obtained containing $85-95 \%$ small lymphocytes. All cultures were done in triplicate, essentially as described by Holt et al. (1966), suspending $10^{\circ}$ mononuclear cells in $1 \mathrm{ml}$ of TC 199 medium enriched with $20 \%$ autologous serum. The cultures were incubated in $5 \%$ $\mathrm{CO}_{2}$ and $95 \%$ air at $37^{\circ} \mathrm{C}$.

Phytohaemagglutinin (PHA) batch BR6 of Burroughs Wellcome Ltd. was used in doses of $10 \mu \mathrm{g}$ per culture, harvesting 72 hours later with $1 \mu \mathrm{Ci}$ of ${ }^{3} \mathrm{H}$-thymidine (Radiochemical Centre, Amersham) added for the last 24 hours to assess the DNA incorporation. The background counts from the unstimulated cultures were subtracted from the counts of the stimulated cultures and the mean of the triplicates was accepted only if there was less than $20 \%$ deviation from that mean. The patients were then expressed as a percentage of known frequently tested normal adults (M.Y. and R.N.) set up with each batch.

Mixed lymphocyte reactions were tested in both directions at the same time, and also one-way only when lymphocytes of the patient (C.P.) and her brother (A.P.) were assessed either as reactive or as immunogen (see Table III). Cultures were labelled with ${ }^{3} \mathrm{H}$-thymidine from 120 hours and harvested at 144 hours.

\section{TISSUE TYPING}

Defibrinated blood samples were obtained from all members of the family. Lymphocyte suspensions were prepared with a Ficoll/Triosil density gradient technique. Thus $1 \mathrm{ml}$ of blood was layered on to $1 \mathrm{ml}$ of Ficoll/Triosil mixture and centrifuged for 20 minutes at 2,000 r.p.m. The lymphocyte layer was removed, washed in phosphate buffered saline, the supernatant discarded, and the lymphocytes were resuspended in complement fixation test diluent and adjusted to $1 \times 10^{8} / \mathrm{ml}$. Each member of the family was tissue typed by a modified microcytotoxicity method (Terasaki and McClelland, 1964) and Westminster Hospital typing plates A (60 antisera) and B (50 less common antisera) were used. The plates containing 1 microlitre quantities of antisera were thawed and $1 \mu \mathrm{l}$. of cell suspension was added to each well. The plates were incubated at $37^{\circ} \mathrm{C}$ for 30 minutes, $2 \mu \mathrm{l}$. of rabbit complement was added and again incubated for a further 30 minutes. Then $1 \mu \mathrm{l}$. of $5 \%$ aqueous eosin was added and the plate examined under phase contrast with an inversion microscope. Reactions giving a cell death 
rate exceeding $20 \%$ above background were taken as positive. The ABO group of each individual was determined. Finally a direct crossmatch, using the recipient serum (C.P.) and the donor lymphocytes (A.P.) was carried out.

\section{CYTOGENETIC STUDIES}

Routine chromosome preparations were obtained before the marrow transplant was undertaken, when the baby was aged 6 months, a microculture method for blood being used (Butler, 1965). Further microcultures were done four months after the bone marrow transplant.

\section{Case History}

The patient (C.P.) was admitted to the Westminster Children's Hospital on 22 November 1970 aged 3 months with a history of loose motions, general malaise, and anorexia, and with septic lesions of her skin and umbilicus. Up till 3 months she had progressed uneventfully. She was the third child of previously unrelated parents, the pregnancy and delivery were normal, and the birth weight was $2,376 \mathrm{~g}$.

A clinical diagnosis of low-grade generalized infection was made but no organisms were grown from blood culture. Her condition
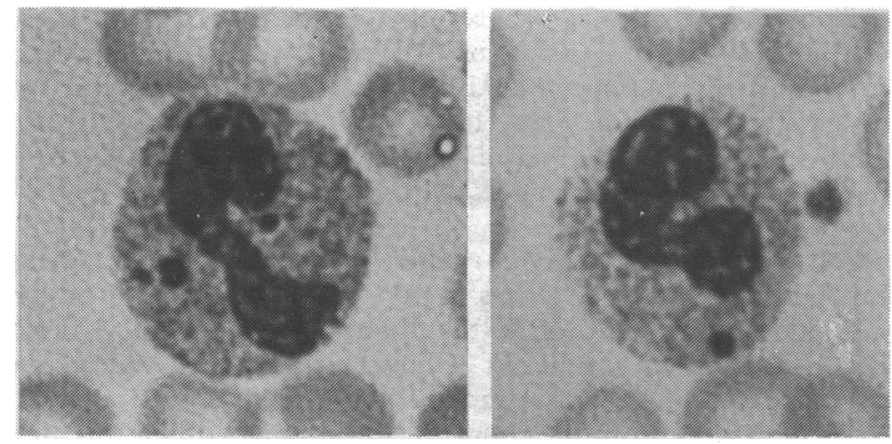

Fig. 1-12\% of the patient's neutrophils before treatment showed cytoplasmic inclusions which stained positively as nucleic acid by the Feulgen method. No viruses were grown from such cells and soon after grafting no further inclusions could be detected.

TABLE I-Results of Immunological Assessment of the Patient

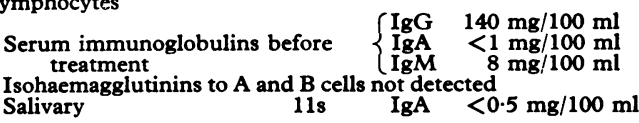

\section{(1) B Lymphocytes}

treatment
Isohaemagglutinins to $A$ and $B$ cells not detected

(2) T-Lymphocytes Peripheral blood "lymphocytes"
DNA uptake in response to PHA
DNA uptake in response to foreign A uptake in $\mathbf{r}$ RNA uptake in response to PHA

$600 / \mathrm{mm}^{3}$
$0-4 \%$ control

$0,0 \%$ control $55 \%$ control

$(170)$
$(11)$
$(19)$
$(>1 / 16)$
$(2)$

(11) (2)

(3) Phagocytosis

$$
\begin{array}{ll}
\text { Absolute neutrophil count } & =2,800 / \mathrm{mm}^{3} \\
\text { Morphology } & =\text { Normal, apart from Fig. } 1 \\
\text { Myeloperoxidase stain } & =\text { Normal } \\
\text { Leucocyte oxidase (NBT test) } & =\text { Normal } \\
\text { Candida killing test } & =\text { Normal }
\end{array}
$$

(4) Complement

C3, C4, C5, C6 levels were within normal limits.

Phagocytosis in fresh compatible normal serum did not differ from that in fresh patient's serum.

(5) Chromosomes (before treatment)

Peripheral blood yielded only a normal female karyotype, as in the upper half of Fig. 5.

(6) Surface markers of lymphocytes

Peripheral blood "lymphocytes" showed no recognizable spots when exposed to fluorescent antisera specific against $\gamma, \ell, \alpha, x$, and $\lambda$ chains (known to stain a proportion of normal lymphocytes).

(7) Plasma factors

The fresh defibrinated plasma of C.P. showed no inhibitory capacity on A.P.'s lymphocytes, nor did C.P.'s washed lymphocytes grow any better in A.P.'s plasma. improved after antibiotic treatment and she was discharged home on 3 December.

Five days later she was readmitted with a recurrence of the skin sepsis. On examination at this stage she appeared to be a well-nourished baby with superficial abscesses of the scalp and face, ulceration of the tongue, and a discharge from the umbilical area. The lung fields were clear to auscultation.

Investigations showed the haemoglobin to be $12.2 \mathrm{~g} / 100 \mathrm{ml}$., and the white blood count 4,000 (77\% neutrophils, $15 \%$ (600) lymphocytes, and $8 \%$ monocytes). It was noted that the polymorphs contained additional nuclear material in the cytoplasm (see Fig. 1). Attempts to isolate viruses (measles, cytomegalic, etc.) were unsuccessful. The significance of this remains undetermined. Chromosomal analysis of peripheral blood confirmed a normal female karyotype, and a buccal smear was chromatin positive. Urine examination was normal, and no pathogens were isolated on culture. The chest $x$-ray picture was initially normal but during the next two months showed increasing evidence of infection.

A falling IgG level with no IgA and very little IgM (see Table I) were noted, and in case there was a delayed maturation of immunoglobulin production treatment was started on 2 January 1971 with intravenous fresh-frozen plasma and intramuscular gammaglobulin. The plasma was fresh frozen to kill any contained immunocytes, pending elucidation of the immune status of the patient. There was little improvement in the infant's general condition. Diarrhoea was the prominent symptom, with increasing excoriation of the buttocks. She also developed infection of the chest, characterized by a severe dry cough and crepitations on auscultation. She lost $2 \mathrm{~kg}$ in weight, becoming grossly wasted. Oral feeding was not tolerated at all by 29 January. From this time for the next two months she was fed almost entirely intra-
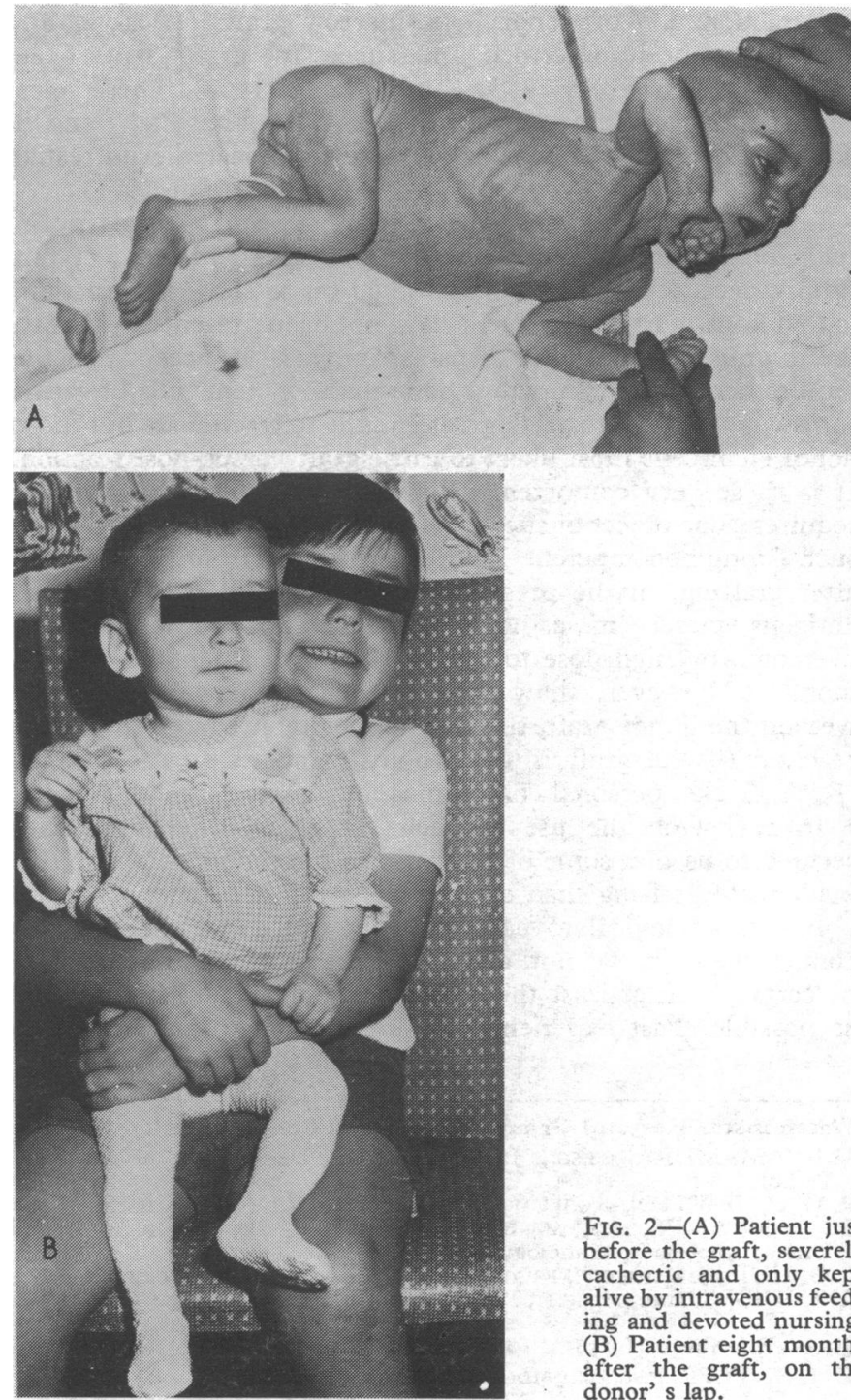

Fig. 2-(A) Patient jus before the graft, severely cachectic and only kept alive by intravenous feeding and devoted nursing. ing and devoted nursing. (B) Patient eight months after the graft
donor's lap. 
venously. Calories and protein were provided by Aminosol preparation plasma and Intralipid.

In view of the progressive nature of the alimentary and respiratory symptoms a combined immune deficiency was suspected. The results of full immunological investigation confirming this diagnosis are given in Table I, whch shows that the baby had lymphopenic hypogammaglobulinaemia, absent isohaemagglutinins, and grossly subnormal lymphocyte response to PHA and foreign lymphocytes. It was also shown that her lymphocytes were poor immunogens (see Table III). Her appearance at this time is shown in Fig. 2 A. Studies of the rest of the family failed to show any immunoglobulin deficiency or any defect in DNA and RNA uptake (as recorded by Fudenberg et al. (1968)) of lymphocytes in response to PHA or foreign lymphocytes. Interestingly the patient's RNA uptake was $55 \%$ of normal.

Tissue typing of the family (see Fig. 3) showed that the patient and her 4-year-old brother were compatible on the basis of blood groups and HL-A loci. The proposed treatment was discussed with the parents. On 18 March marrow transfusion was carried out by the technique described below.

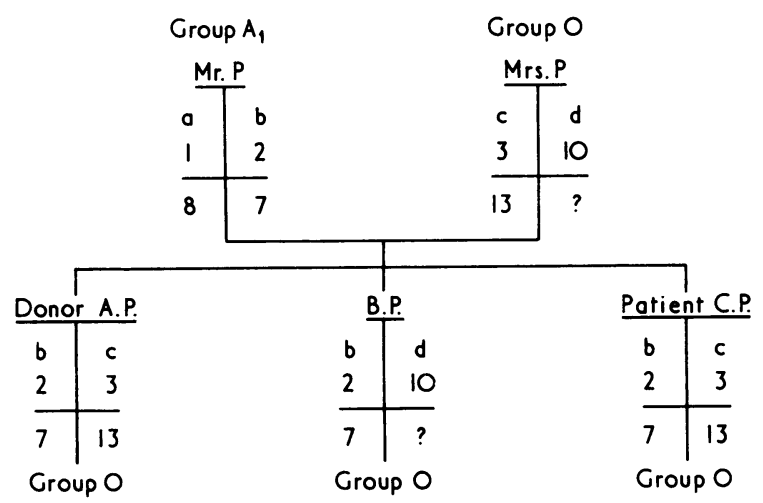

Fig. 3-Results of tissue typing and blood grouping. It is clear from the diagram that A.P. and C.P. are identical for HL-A antigens and that A.P. was the best choice as a donor for the marrow transfusion to the patient. The sera of C.P. and A.P. showed no cross-cytotoxicity and the mixed lymphocyte reaction between them showed no detectable increase in DNA uptake. The competence of the lymphocytes of A.P. was confirmed by DNA uptakes after PHA at $188 \%$ and mixed with foreign lymphocytes at 100 $135 \%$ of the control; with R NA uptake at $238 \%$ control. A.P. had normal salivary and serum immunoglobulin levels: serum IgA was $76 \mathrm{mg} / 100 \mathrm{ml}$ ( $31 \%$ of mean adult normal).

\section{BONE MARROW TRANSPLANTATION}

Marrow was aspirated by multiple punctures under general anaesthesia from the posterior iliac crests from the patient's brother (A.P.), who was shown to possess identical HL-A antigens to the patient's. The technique used was a completely closed system developed in these laboratories by Pegg and Kemp (1960) and Pegg (1966). Because of the relatively small volume of marrow that could be aspirated from a small child, the apparatus was modified by substituting siliconized universal containers with a hole punched through the metal cap instead of a siliconized blood transfusion bottle. The aspirated material was passed through stainless steel fine sieves as described by Pegg (1960). The sieved material was returned to the universal containers which were then centrifuged, the fat layer and the supernatant plasma were removed by sterile aspiration and the deposits collected into one syringe and injected slowly into a freely running intravenous drip to the patient. The total volume administered was $12.5 \mathrm{ml}$, having a cellularity of $22 \times 10^{6} / \mathrm{ml}$-that is, a total cell transfusion of 2.75 $\times 10^{8}$ cells.

A stained sample of the material thus injected showed myeloid and erythroid cells of all stages of development with normal lymphocytes and monocytes and some megakaryocytes. The myeloid: lymphoid ratio was approximately 6:4. A "viability" test using the fluorescent acridin orange technique (Hittmann, 1967) showed $94 \%$ of the cells to be viable. The donor suffered little disability and he did not complain of bruising at the site of punctures. It was noted that before the cell transfusion about $12 \%$ of the patient's segmented neutrophils showed one or more Feulgen-positive cytoplasmic granules (Fig. 1). Cells bearing these granules could not be found after the cell transfusion. The significance of these findings is obscure.

\section{SUCCESS OF THE GRAFT}

There were no immediate or late untoward signs or symptoms following the infusion of marrow. Her immediate postgrafting course was complicated by an acute mastoiditis which was treated by cortical mastoidectomy and drainage. This procedure was well tolerated.

One week after the marrow infusion there started to be slow improvement in the diarrhoea, and gradually over the next two weeks the stools became semiformed. It was then possible gradually to introduce oral feeding without re-exacerbation of the diarrhoea. She was regraded on to Velactin with vitamin supplements.

The excoriation of the buttocks started to granulate and healed during the four weeks following the transplant. There was also improvement in her respiratory symptoms both clinically and radiologically which previously had been unchanged by antibiotic therapy.

Four weeks after the marrow infusion the lymphocytic transformation rose to $8 \%$. At the same time there was a reticulocytosis of $10 \%$ and the haemoglobin then rose from 8 to $10 \mathrm{~g} / 100 \mathrm{ml}$. Her weight and general well-being also started to improve about the same time, and she was allowed home on 15 June 1971, with no special precautions, apart from Velactin feeds.

TABLE II-Results of Immunological Assessment of Patient after the Bone Marrow Graft (see also Fig. 4)

(1) B-Lymphocytes

Serum IgG level rose to $1,800 \mathrm{mg} / 100 \mathrm{ml}$ within two months and has since emained within normal limits for age.

Serum IgM level has been as high as $240 \mathrm{mg} / 100 \mathrm{ml}$, otherwise being within normal limits for age. Isohaemagglutinins, however, had not become dectable by 13 December 1971 .

Serum IgA level had risen to $70 \mathrm{mg} / 100 \mathrm{ml}$ on 13 December 1971, finally within normal range for age.

11s IgA + secretory piece has been confirmed by immunoelectrophoresis

(2) T-Lymphocytes

Peripheral blood lymphocytes rose to $1,200-2,100 / \mathrm{mm}^{2}$

DNA uptake in response to PHA has slowly risen to $63 \%$ of control.

DNA uptake in response to foreign lymphocytes has risen to $14,15 \%$ of

(3) and (4) Not retested.

(5) Chromosomes

Over 100 cells were examined: $25 \%$ showed a normal female karyotype, $75 \%$ contained the Y-chromosome with a normal male karyotype (presumably from her brother). (See Fig. 5.) No hypermodal counts or chromosome
breaks were detected.

(6) Surface markers Peripheral blood "lymphocytes" now showed typical spots when stained
as in Table I.
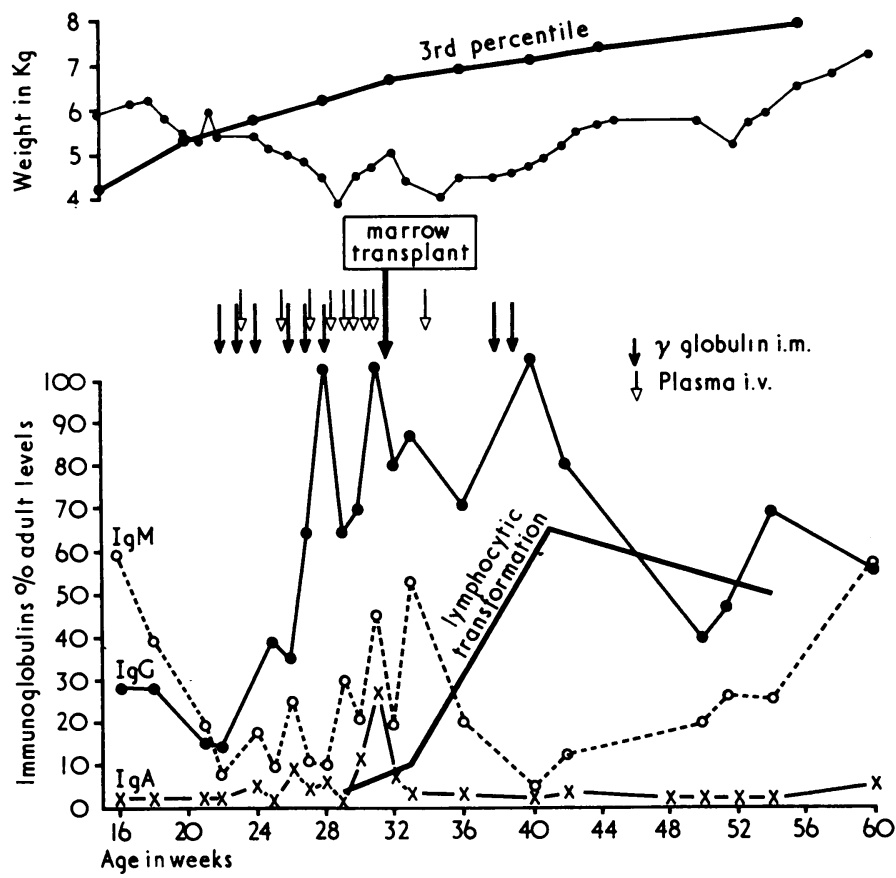

FIg. 4-Progress of the patient. The spontaneous decline of IgM with no emergence of her own IgG or IgA, were partially corrected by $\gamma$-globulin and fresh frozen plasma. This, however, was inadequate as evidenced by her continued loss of weight. After the bone marrow graft, T-lymphocyte function appeared for the first time, IgG (the dominant marrow B-lymphocyte) rose first followed by IgM and finally IgA. 
She failed to gain any significant weight and an episode of diarrhoea led to her readmission on 26 July. Stool culture showed a pathogenic Escherichia coli, strain 0127 , and at the same time the serum IgM level rose from 190 to $250 \mathrm{mg} / 100 \mathrm{ml}$, although no specific antibody to $\mathrm{O} 127$ could be detected.

She was treated with clear fluids by mouth, together with neomycin, and again regraded to full-strength Velactin. Her stools became normal and she started to gain weight. The cough which had been persistent since her first admission had only partially improved and her sputum was purulent, growing predominantly haemophilus. This was not eradicated with ampicillin, and a bronchogram was performed in the event of underlying bronchiectasis. No severe structural damage was detected. It is relevant that up to 15 June no IgA could be detected in her serum or saliva-that is, apart from plasma infusions. By 26 July IgA became detectable in the serum and by 11 October it had appeared in the saliva. The cough was still present but not as productive or as pronounced as previously. She was gaining weight and on 31 January 1972 weighed $9.6 \mathrm{~kg}$ (10th percentile) and her length was $75 \mathrm{~cm}$ (3rd percentile)

Throughout this period saliva and sera were examined by the method of Rádl (1970) for any emerging monoclonal proteins (as reported by Koning et al., 1969) but none have as yet been detected. A summary of the postgraft immunological status is given in Table II and shown in Fig. 4. The chromosome analysis of her now competent lymphocytes is given in Table II and Fig. 5. Chimaerism was established with convincing proof of the survival and proliferation of the transplanted male cells. Furthermore, the lymphocytes from the patient were now potent as immunogen (see Table III).
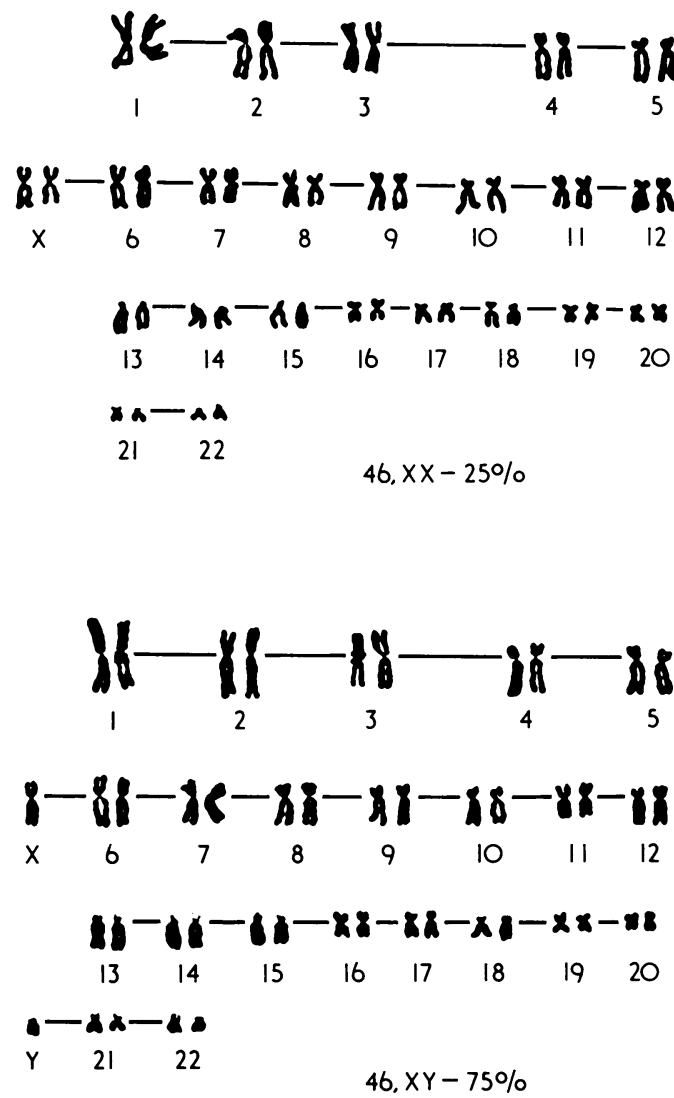

FIG. 5-Results of karyotyping dividing cells obtained from patient's peripheral blood three months after grafting. TABLE III-Immunogenicity of Lymphocytes of C.P. and A.P., One-way to
Controls M.Y. and R.N. DNA Uptakes as a Percentage of the Control's Controls M.Y. and R.N. DNA Uptakes as a Percentage of the Control's
Response to PHA. Although C.P. and A.P. are HL-A Identical, only after Response to PHA. Although C.P. and A.P. are HL-A Identi
Grafting do C.P.'s Lymphocytes really show Immunogenicity

\begin{tabular}{|c|c|c|c|c|}
\hline $\begin{array}{l}\text { M.Y. } \\
\text { M.Y. } \\
\text { M.Y. }\end{array}$ & $\begin{array}{l}\rightarrow \\
\vec{\rightarrow}\end{array}$ & $\begin{array}{lcc}\text { C.P.P. } & \cdots & \ldots \\
\text { AC.P." (after graft) }\end{array}$ & $\begin{array}{l}. \\
\because\end{array}$ & $\begin{aligned} &< 1 \% \\
& 24 \% \\
& 19 \%\end{aligned}$ \\
\hline $\begin{array}{l}\text { R.N. } \\
\text { R.N. } \\
\text { R.N. }\end{array}$ & $\begin{array}{l}\dot{\rightarrow} \\
\vec{\rightarrow}\end{array}$ & $\begin{array}{lcc}\text { C.P. } & \ldots & \ldots \\
\text { A.P. } & \text { "C.P." (after graft) }\end{array}$ & $\begin{array}{l}. \\
\therefore\end{array}$ & $\begin{array}{l}<1 \% \\
35 \% \\
19 \%\end{array}$ \\
\hline
\end{tabular}

\section{Discussion}

Although the onset was unusually late there can be little doubt the patient was near death from a severe combined immune deficiency syndrome. While impaired lymphocyte reactions can be acquired with marasmus (Geefhuysen et al., 1971) complete abrogation is unrecorded. The appearance of some detectable serum $\operatorname{IgM}$ is also recorded in several other patients with combined immune deficiency (Hobbs, 1969) as is the late onset. The possibility of chimaerism or in utero graft-versus-host reaction is contradicted by the clearly normal chromosomal pattern and the uniformity of HL-A typing before the bone marrow transplant. The neutrophil inclusions stained as nucleic acid but remain an enigma: no viruses have been isolated.

The grafting of HL-A identical sibling bone marrow is a calculated risk (Graw et al., 1970). In that "lymphocytes" from our patient were poor immunogens (see Table III) yet apparently HL-A identical to normally immunogenic lymphocytes, the genesis of mixed lymphocyte reactions must involve more than HL-A alone and for such patients might be misleading. Perhaps other cells-for example, neutrophils - should be tested against potential donors; alas skin or buccal mucosal cells are likely to be infected. Despite the risks HL-A sibling grafts have been successful with at least two survivals over one year (Gatti et al., 1968; Koning et al., 1969). The rate of assumption of normal $\mathrm{IgG}$ and IgM levels and the rate of reversal of marasmus in the present instance were more rapid than in previous patients (see Fig. 4) and perhaps attributable to the adequate dose of unmolested cells that was risked, a finding now supported by others (Levey et al., 1971). This may also explain why no monoclonal proteins have yet been seen. Experience of over 100 previous bone marrow grafts was available at Westminster where good technique was developed by 1960 for other purposes, and no doubt the baby also benefited from the expertise available. She was still underweight for her age but was vastly better (see Fig. 2A and B) and up to 10 months later had shown none of the signs of graft-versus-host reaction.

The delay in maturation of her IgA can be attributed to the donor, whose own serum level was only $31 \%$ of the adult mean, partially reflecting his bone marrow. That secretory IgA has now appeared in the recipient argues in favour of the $\operatorname{IgA}$ lamina propria populations being derived from a common pool of $7 \mathrm{~s}$ IgA-synthesizing B-lymphocytes.

The acquisition of the Y-chromosome in the dividing cells of her peripheral blood indicates that her brother's graft had taken, and so far successfully, in the face of widespread infection and near-fatal cachexia. Furthermore, it seems clear that bone marrow alone can correct such a defect and thymus and peripheral blood buffy coat seem unnecessary. We therefore feel others, when confronted with such a usually fatal situation, should not be put off by complicated techniques but should indeed at least attempt adequate simple bone marrow grafting if a suitable donor is available.

We gladly acknowledge that the devoted nursing at the Westminster Children's Hospital contributed to the survival of the patient, together with the help of many colleagues, especially $\mathrm{Dr}$. I. M. Anderson for help and encouragment with the patient who was admitted under his care, and $\mathrm{Mr}$. C. A. Holborow for the timely mastoidectomy.

For financial support for the extensive laboratory work we are indebted to the governor's Discretionary Fund of the Westminster Group of Hospitals and to the Lawson and Fane Trusts.

We thank the following for the generous supply of tissue typing sera: Dr. H. Festenstein, the London Hospital; Dr. J. Ray, National Institutes of Health, Bethesda; and Dr. G. Tovey, Bristol. We also thank Miss Jill Ross for able help.

\section{References}

Barnes, R. D., et al. (1969). Lancet, 1, 168

Butler, L. J. (1965). Human Chromosome Newsletter, 15, 5.

Dicke, K. A., Hooft, J. I. M. van, and Bekkum, D. W. van (1968). Transplantation Bulletin, 6, 562. 
Fudenberg, H. H., Kamin, R., Salmon, S., and Tormey, D. C. (1968). Proceedings of the Third Nobel Symposium, ed. J. Killander, p. 585. Stockholm, Almqvist and Wiksell.

Gatti, R. A., Meuwissen, H. J., Allen, H. D., Hong, R., and Good, R. A.

Geefhuysen, J., Rosen, E. U., Katz, J., Ipp, T., and Metz, J. (1971). British Medical fournal, 4, 527.

Graw, R. G., et al. (1970). Lancet, 2, 1053.

Graw, R. G., et al. (1970). Lancet, 2, 1053

Hobbs, J. R. (1969). Primary Immune Paresis in Immunology and Development, ed. A. Adinolfi, p. 114. London, Heinemann.
Hobbs, J. R. (1970). Association of Clinical Pathologists Broadsheet, No. 68. Holt, L. J., Ling, N. R., and Stanworth, D. R. (1966). Immunochemistry, 3, 359.

Koning, J. de, et al. (1969). Lancet, 1, 1223.

Lehrer, R. I., and Cline, M. J. (1969). Fournal of Bacteriology, 98, 996.

Levey, R. H. et al. (1971). Lancet, 2, 571.

Pegg, D. E. (1960). Lancet, 1, 682.

Pegg, D. E. (1966). Bone Marrow Transplantation. London, Lloyd-Luke.

Pegg, D. E., and Kemp, N. H. (1960). Lancet, 2, 1426.

Pegg, D. E., and Kemp, N. H. (1960).

Terasaki, P. I., and McClelland, J. D. (1964). Nature, 204, 998.

\section{PRELIMINARY COMMUNICATIONS}

\section{Treatment of Soft-tissue Injuries by Pulsed Electrical Energy}

\author{
D. H. WILSON
}

British Medical fournal, 1972, 2, 269-270

\section{Summary}

Twenty pairs of patients matched for sex, age, weight, and degree of trauma were treated either with an active Diapulse machine emitting pulsed, high-frequency electrical energy or with a non-active placebo machine. They were examined for swelling, pain, and disability before treatment and after three days under doubleblind conditions. The results show that the pulsed, highfrequency electrical treatment has a definite biological effect on recently injured soft tissues, especially in the reduction of pain and disability.

\section{Introduction}

The interrelation of mechanical stress and electrical charges in collagen fibres has been examined in vitro in both tendon and bone (Fukada and Yasuda, 1957, 1964; Bassett and Becker, 1962; Bassett, 1965; Shamos and Levine, 1967) and attempts have been made to use electrical energy to stimulate the repair of collagen fibres in vivo (Ginsberg, 1961). Recently J. M. Fitton and S. Hulman (personal communication, 1971) reported favourably on a subjective trial of pulsed, high-frequency electrical energy in the treatment of soft-tissue injuries. In view of this a double-blind trial was planned to make a statistical assessment of this treatment in patients suffering from a recent sprain of the lateral ligaments of the ankle joint.

\section{Patients and Method}

Patients who had sustained an inversion injury of the ankle during the preceding 36 hours were examined physically and radiologically to exclude a bony injury or a ligamentous instability of the ankle. They were then graded for swelling, pain, and disability and paired for age, weight, sex, and degree of injury.

Diapulse machines were used to give the patients pulsed, high-frequency electromagnetic radiation. These machines give

Accident and Emergency Department, General Infirmary, Leeds 1 D. H. WILSON, F.R.C.s., Consultant Surgeon a 975 -watt emission for 65 microseconds at $27 \cdot 12$ megacycles with a resting interval between successive pulses of 1,600 microseconds. Patients received continuous treatment for one hour and were treated daily for three days. After each treatment crêpe bandages were applied from the toes to the calf and the patients were given walking instruction and exercises by an experienced physiotherapist.

\section{DETAILS OF DOUBLE-BLIND TRIAL}

Six Diapulse machines were used, designated by random letters from the alphabet and arranged in three pairs. A fuse was removed from one of each pair of machines so as to have one functional and one placebo machine in each pair. The code indicating which machines were functional was placed in a sealed envelope by the electrician and it was not opened until the trial had been completed. Patients receiving treatment from a Diapulse machine are not aware of any sensation as there is no heating of the tissues. Thus neither the patients nor the clinician who examined them knew which patients had received electrical treatment and which had the placebo.

\section{GRADING OF PATIENTS' SIGNS AND SYMPTOMS}

Patients were examined before treatment on the first day and after treatment on the third day, and on each occasion were graded on a 0-4 scale for swelling, pain, and disability (TableI).

TABLE I-Numerical Grading of Signs and Symptoms

\begin{tabular}{|c|c|c|}
\hline Signs & Grade & Symptoms \\
\hline Swelling & $\begin{array}{l}0 \\
1 \\
2 \\
3 \\
4\end{array}$ & $\begin{array}{l}\text { No increase of ankle circumference compared with } \\
\text { uninjured ankle } \\
\text { Increased circumference of } 0-\frac{1}{2} \text { in }(1.3 \mathrm{~cm}) \\
\text { Increased circumference of } \frac{1}{2}-1 \text { in }(1 \cdot 3-2 \cdot 5 \mathrm{~cm}) \\
\text { Increased circumference of } 1-1 \frac{1}{2} \text { in }(2 \cdot 5-3.8 \mathrm{~cm}) \\
\text { Increased circumference of over } 1 \frac{1}{3} \text { in }(3.8 \mathrm{~cm})\end{array}$ \\
\hline Pain & $\begin{array}{l}0 \\
1 \\
2 \\
3 \\
4\end{array}$ & $\begin{array}{l}\text { No pain } \\
\text { Pain only after walking some distance } \\
\text { Pain on taking even one step } \\
\text { Pain when at rest on couch } \\
\text { Pain severe enough to require analgesics }\end{array}$ \\
\hline Disability & $\begin{array}{l}0 \\
1 \\
2 \\
3 \\
4\end{array}$ & $\begin{array}{l}\text { No disability } \\
\text { Walks with slight limp } \\
\text { Walks with considerable difficulty } \\
\text { Can walk only with help of supporting arm } \\
\text { Cannot walk at all }\end{array}$ \\
\hline
\end{tabular}

\section{Results}

The scores of the 20 placebo patients (Table II) and the 20 treated patients (Table III) in each of the measured categories of swelling, pain, and disability were added together. In each category the percentage improvement in the treated patients was about twice that of the placebo patients. 